Historic, Archive Document

Do not assume content reflects current scientific knowledge, policies, or practices. 

SPECIAL OFFER OF

\section{Palisades Popular Perennials}

THE KIND OUR GRANDMOTHERS GREW

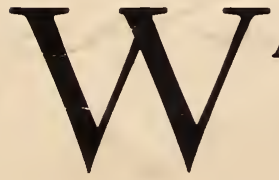

AS it ever brought to your notice how inexpensive

it is to acquire a permanent flower garden that will last for generations?

After dreary winter is past how fondly we look forward to seeing old associates of spring and summer time, who call annually without the ceremony of digging or planting!

There are few things that call to mind more vividly pleasant recollections of our early life than the sight or odor of a simple flower, loved perhaps by some relative or friend; and what would be a more suitable remembrance than to plant such a one so that it may be called his or hers for time to come?

We give on the seventh page of this circular a list of one hundred kinds with botanical and familiar names, with some of which you may have a fellow-feeling, and if planted even in the least conspicuous corner or border they will make it the most interesting part of the garden.

\section{THE PALISADES NURSERIES, INC. SPARKILL, N. Y.}


Wilhelm Miller says in the Garden Magazine: "But now that the treasures of the Far East are lavished upon us, we have hardy plants suitable for practically every purpose the most exacting gardener can conceive. And wherever we have any special object to accomplish, we ought to try nine times to find a hardy plant that will do the work before falling back on a tender one. And this for two reasons: First, hardy plants harmonize better with our climate and environment than tropical plants. Second, as a rule, they are cheaper to maintain. And, in the long run, those effects which grow naturally out of the soil, and out of true economy, will be recognized as the most artistic."

\section{TO ENCOURAGE THEIR USE WE ARE MAKING THIS SPECIAL OFFER}

You may select from one to one thousand in any assortment (or we will make a selection for you) at the prices named below, and we deliver without further expense to your express or post-office (our option) strong plants of varieties named on seventh page of this circular. When a preference for certain varieties of the kinds named is given we will try to comply, otherwise our selection will be sent.

PRICES at which we will deliver, express and postage paid, strong plants of the varieties named on page 7 of this circular.

\begin{tabular}{|c|c|c|c|c|c|c|c|c|c|c|c|}
\hline ny & 1 plant for & $r \quad 15 c$. & Any & & ints & for $\$ 2.25$ & Any & 250 & lan & for & $\$ 15.00$ \\
\hline 8 & 5 & $50 c$. & ، & 50 & " & 4.00 & & 500 & “ & “" & 27.50 \\
\hline “6 & 10 & $\$ 1.00$ & ““ & 100 & “" & 7.00 & "، & 1000 & “ & “ & 50.00 \\
\hline
\end{tabular}

WHEN ORDERING REFER TO THIS SPECIAL OFFER AS XXX

Complete catalogue sent on application 


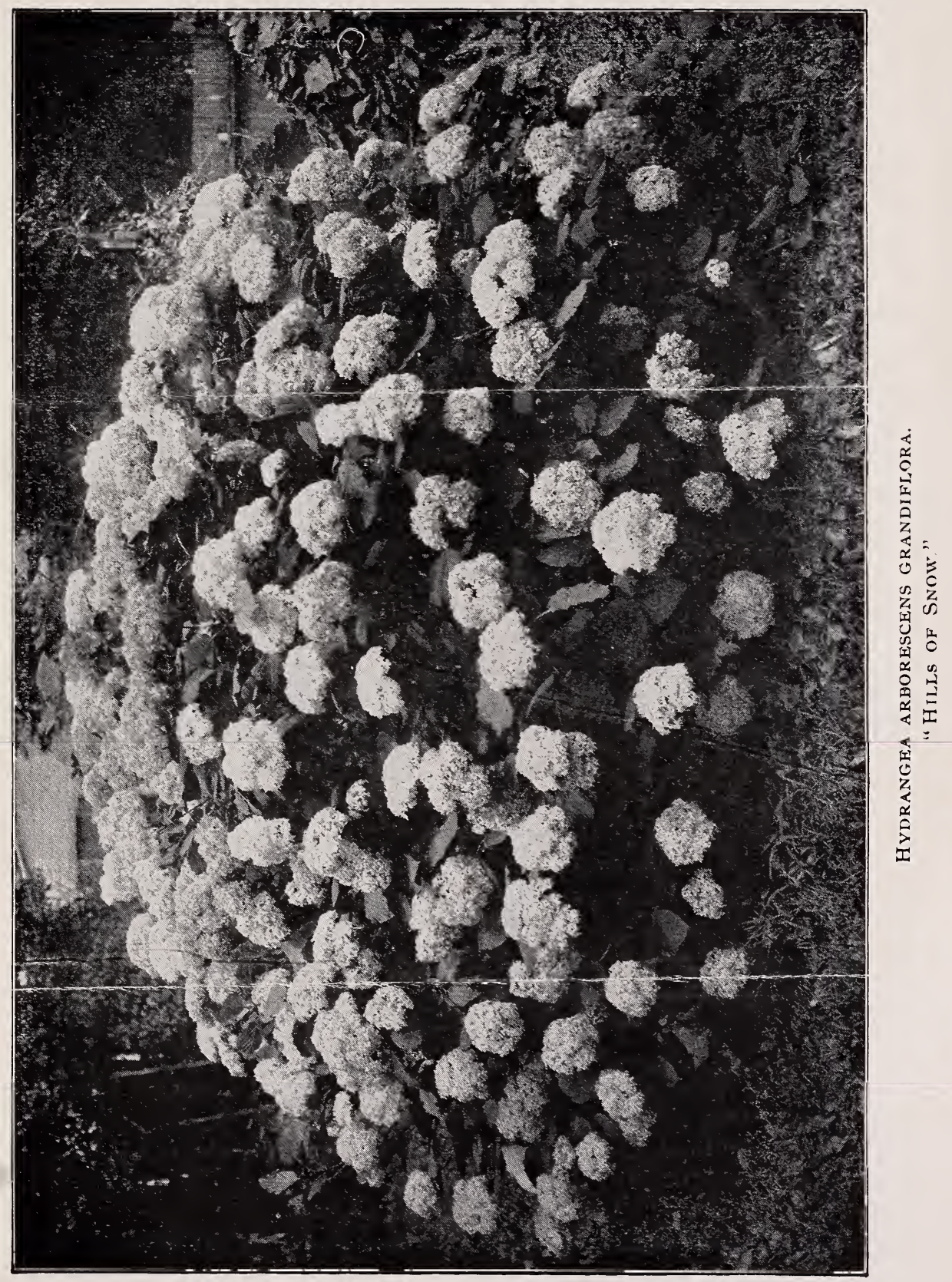




\section{Hydrangea Arborescens Grandiflora.}

\section{"HILLS OF SNOW."}

This superb new Hydrangea is a variety of the hardy native species $H$. arborescens, commonly found "wild" in most of the states east of the Mississippi river. The variety grandiflora is likewise absolutely hardy and is, moreover, of easy culture and is an exceedingly prolific bloomer. A five year old plant has produced one hundred and twenty-six perfect blooms at one time.

The size of the flower is one of the striking features of this shrub. The large flower shown on the first page of this circular measured nine by twelve inches. Twelve inch blooms are frequent. on young plants, while the average size on matured plants is usually six inches or more.

The color of the flower is a pure snowlike white, without the creamy and later pink tints that are characteristic of the $H$. paniculata grandiflora. The length of time this whiteness is retained depends somewhat on local conditions, but usually frcm four to five weeks, when the flowers begin to change slowly and gradually to a light green color, and by October the foliage and flowers are of a similar shade. The flower clusters remain intact long after the leaves have fallen, and frequently throughout the following winter.

This Hydrangea gives every promise of becoming even more popular than the well known $H$. paniculata grandiflora, as it lacks the coarseness and stiffness of that variety; it is refined in tone and effect, and with its abundant and handsome foliage it lends itself readily to landscape effects. It is a comely, handsome shrub at all times. It reaches a height of five to six feet, and when in full bloom is one of the most striking as well as the most beautifu1 shrubs of its season, suggesting the descriptive synonym referred to in Bailey's "Cyclopedia of American Horticulture," viz.: "Hills of Snow."

Price of 2 yr. old field grown plants, 2 to $3 \mathrm{ft}$., 3 to 5 stems, $35 \mathrm{cts}$. each, $\$ 3.50$ per doz.; I to 3 stems, 25 cts. each, $\$ 2.50$ per doz.

Price of Plants from 3 -inch pots, I5 cts. each, $\$ 1$.oo per doz., $\$ 6.00$ per Ioo. All will flower the first year.

\section{PALISADES NURSERIES, Inc.}

SPARKILL, N. Y. 


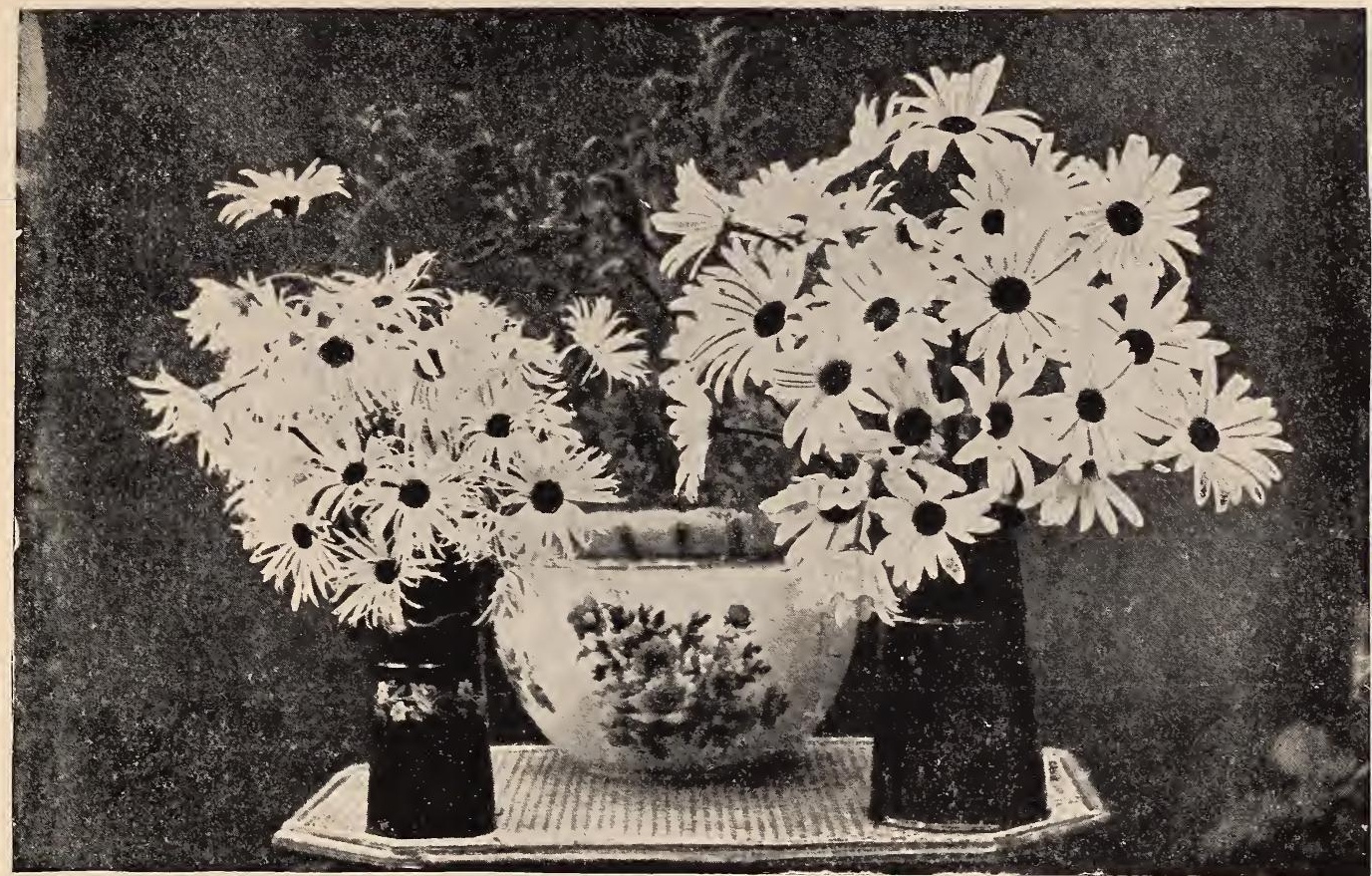

CHRYSAN IHEMUM MAXIMUM (Tne Shasta Daisy, California). This fine species ranks among our best, showiest, and most valuable hardy summer-flowering border plants: for cutting they are invaluable, their large snowy white Daisy-like flowers lasting long in water, while in the border they make elegant bushes, smothercd in blossom: all quite hardy, and suitable for any ordinary garden soil. July and August flowering.

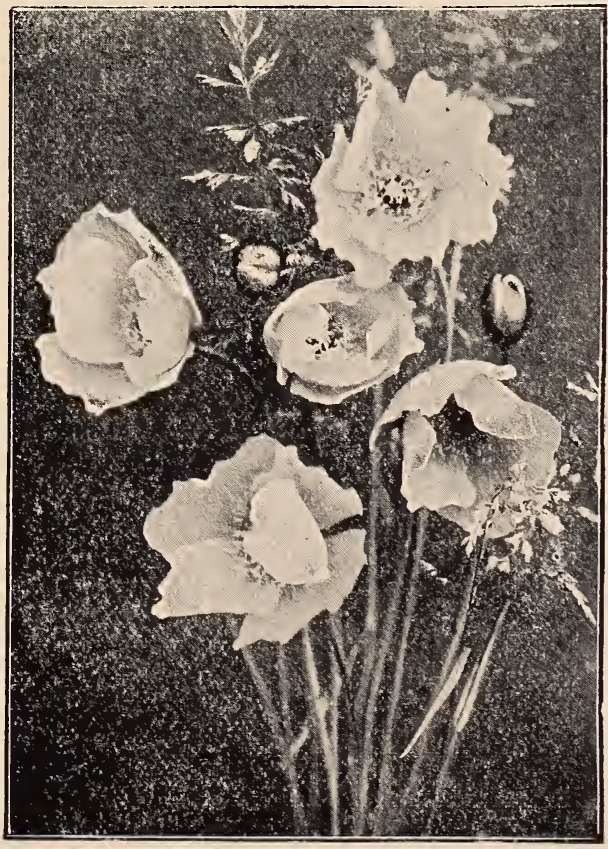

PAPAVER NUDICAULE. (Alpine Poppies.)

Elegant dwarf Poppies with abundance of graceful showy flowers from May to September. Prized for cutting. As border plants it would be impossible to over-estimate their value. Height $1 \mathrm{ft}$.

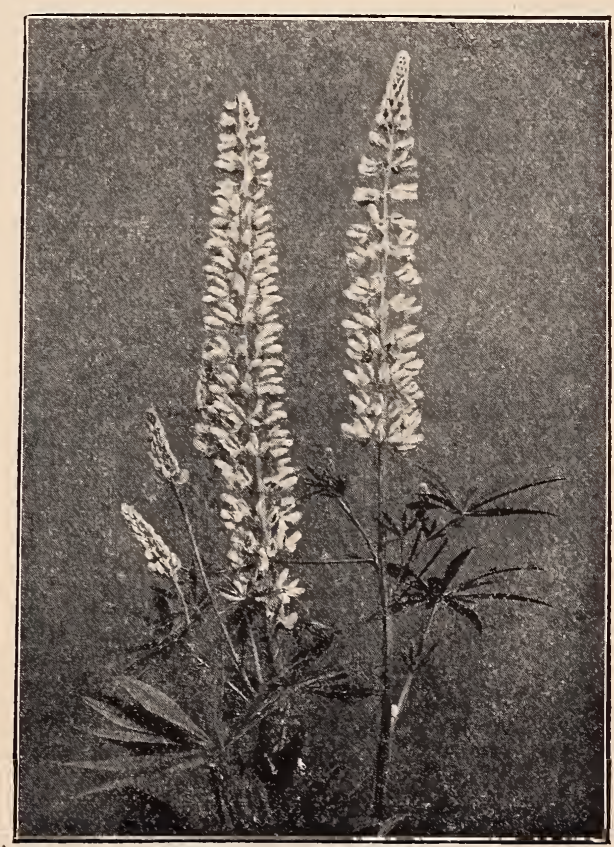

LUPINUS POLYPHYLLUS

(The old-fashioned Garden Lupin)

Bearing stately spikes of blue, white and pink flowers in June. Height $3 \mathrm{ft}$. 


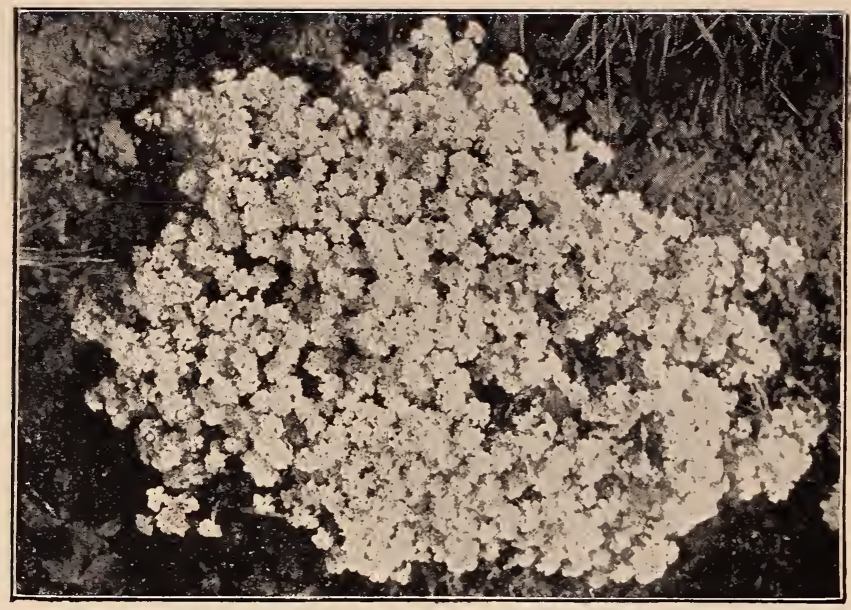

\section{ALYSSUM (Sweet Alyssum or Mad Wort)}

Effective in beds, edgings borders or on rockwork: the sheets of yellow flowers contrast charmingly in spring with Arabis. They thrive in any soil in a sunny position

\section{GYPSOPHILA PANICULATA}

(Chalk Plant or Babies' Breath)

A graceful border plant, growing into a compact bush 2 to $3 \mathrm{ft}$. high, smothered in summer with small white flowers; very elegant in table bouquets, etc.
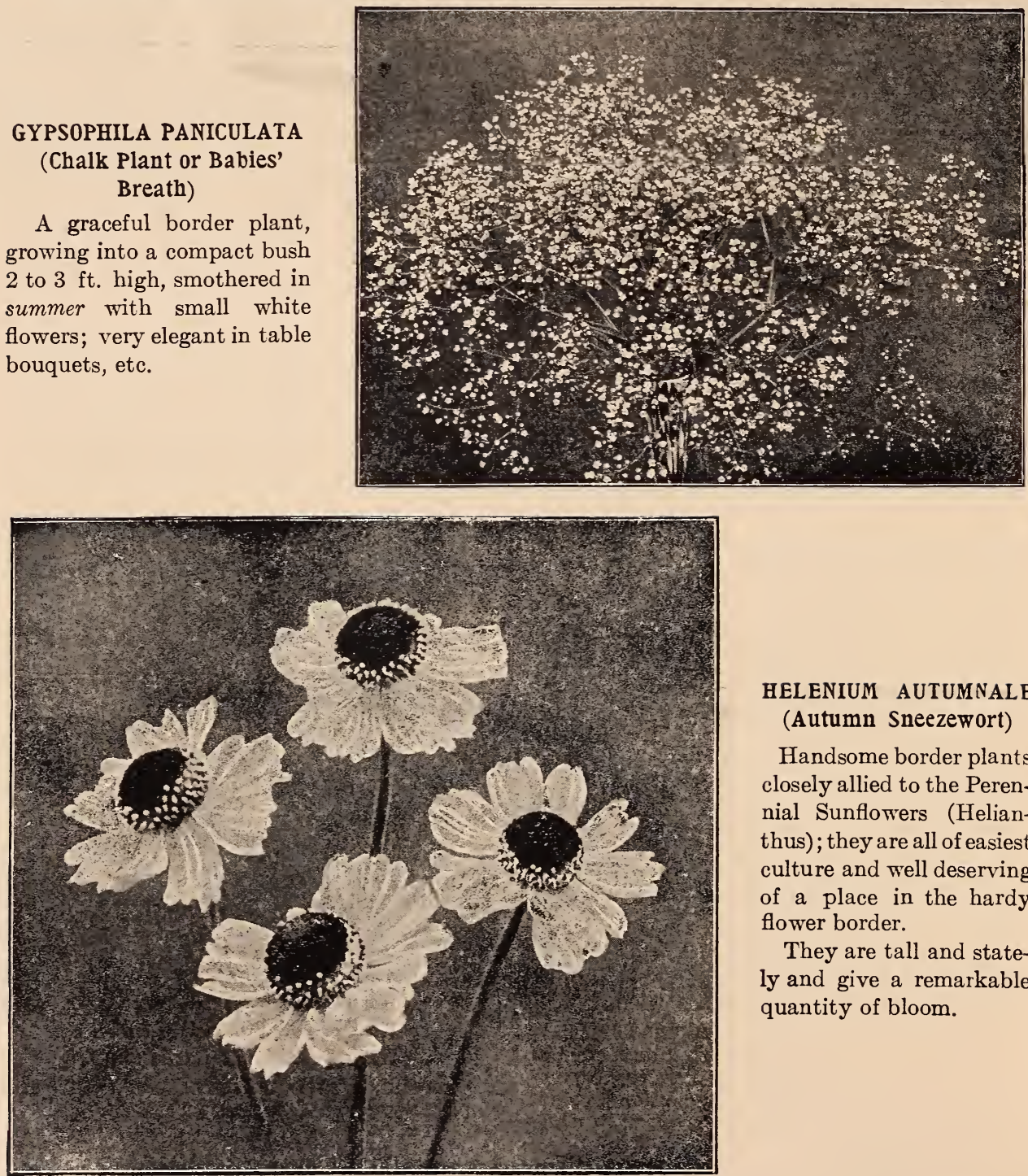

HELENIUM AUTUMNALE (Autumn Sneezewort)

Handsome border plants closely allied to the Perennial Sunflowers (Helianthus); they are all of easiest culture and well deserving of a place in the hardy flower border.

They are tall and stately and give a remarkable quantity of bloom. 


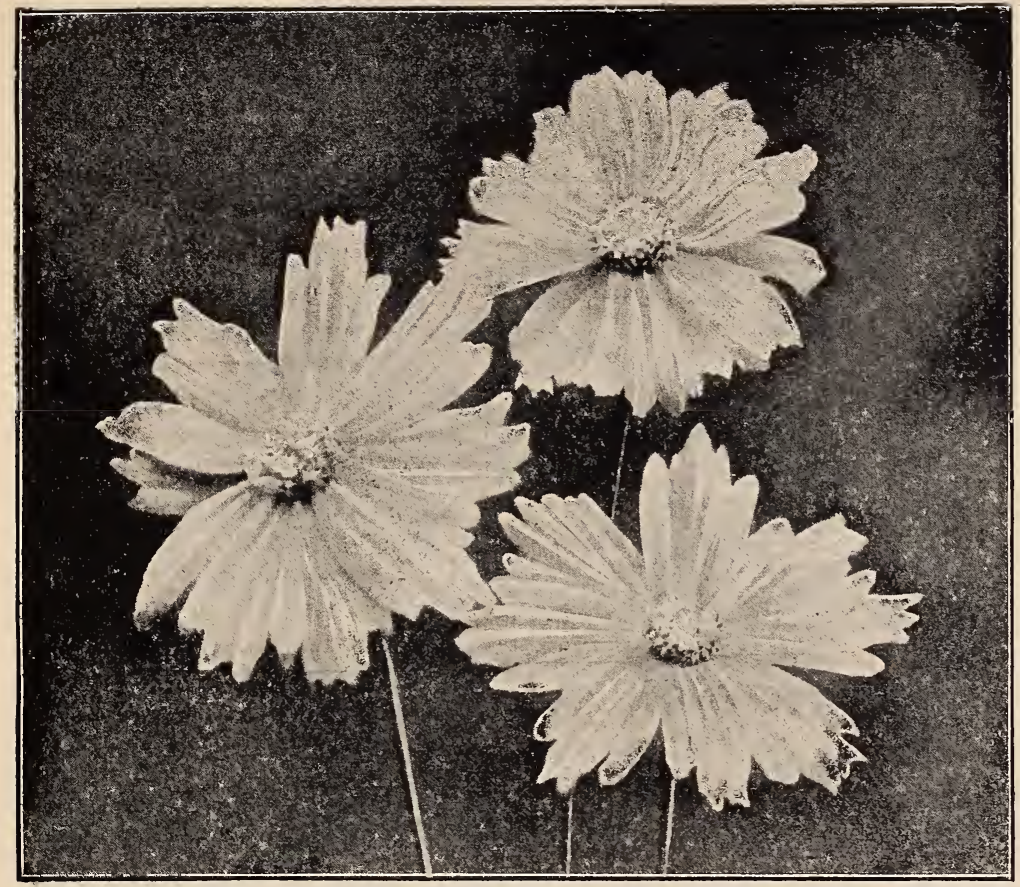

\section{COREOPSIS (Lanceolata \\ Grandiflora)}

Valuable border plants,supplying throughout summer abundance of showy elegant yellow flowers, much prized for cutting. They are of the easiest culture, thriving even in town gardens, where their bright-colored flowers are greatly appreciated.

\section{AQUILEGIA}

(Columbine)

Few plants lend themselves to naturalization more readily, or look more beautiful in grassy glades and woodland walks, than the Columbines; they grow and thrive in shady nooks and corners where most plants have to struggle for existence. In borders their graceful beauty is highly appreciated, while the flowers are invaluable for cutting.

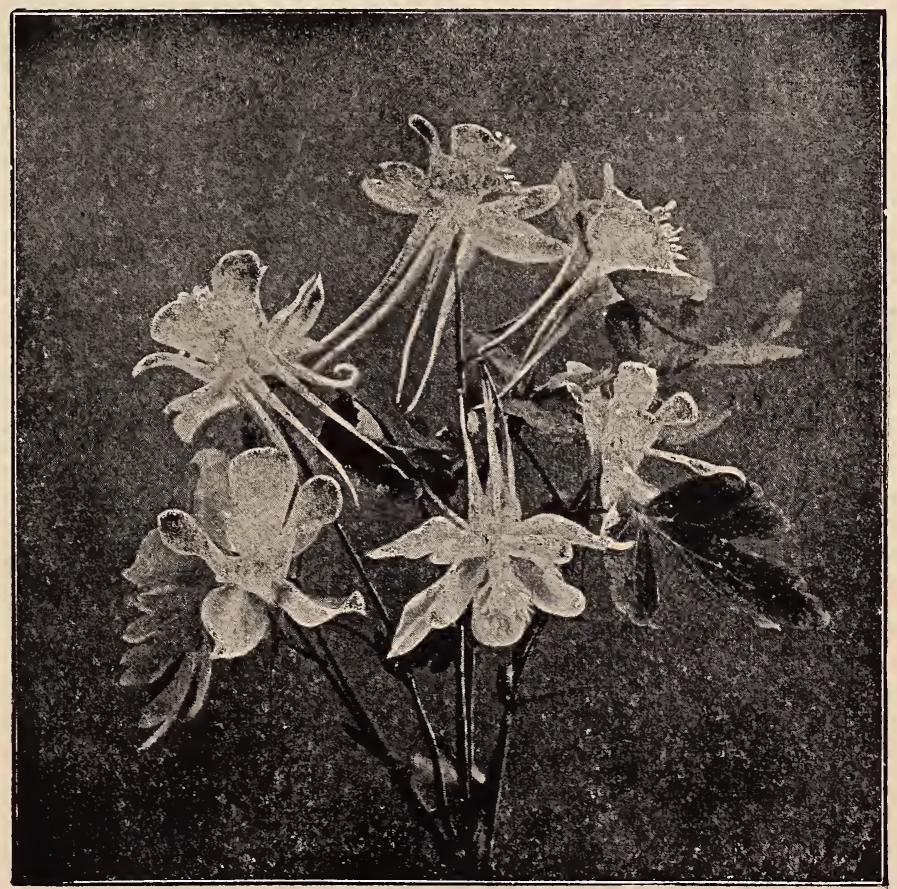




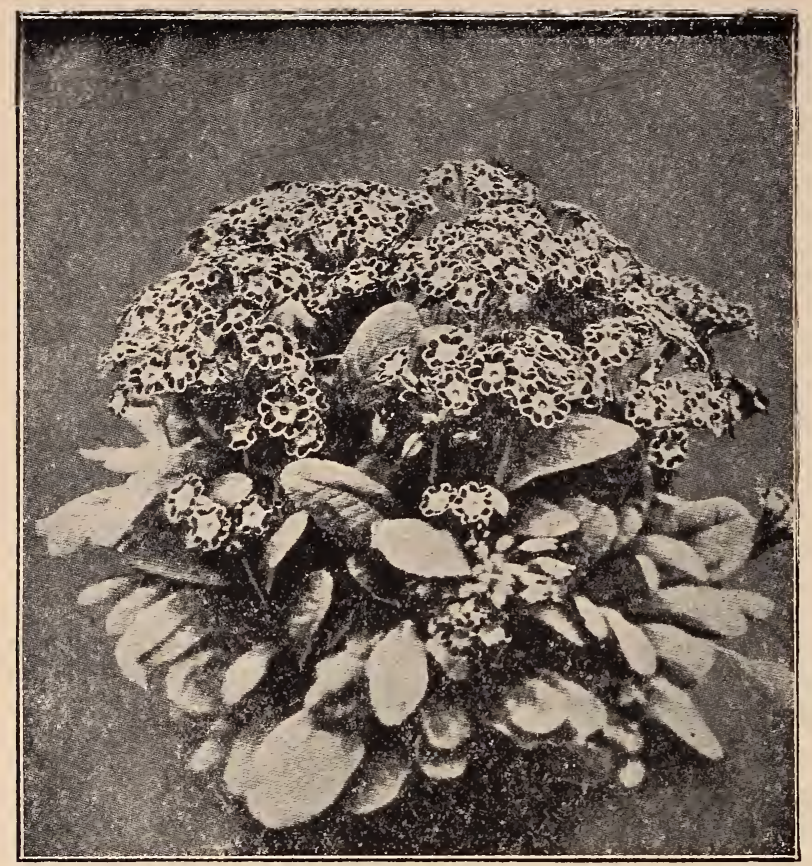

\section{PRIMULA \\ (Hardy English Primrose)}

A Primula garden is a charming sight, and once seen is not soon forgotten. Naturalized in shady spots on rockeries and on walls, etc. These Alpine gems present a lovely picture in spring and early summer. All hardy. Most varieties stand gentle forcing and are much in demand at Easter.

\section{WALLFLOWER (English)}

No plant is more esteemed in an English garden than the Wallflower, on account of their very fragrant flowers, the colors of which run from pale yellow to deepest bloodred, and are very useful for cutting.

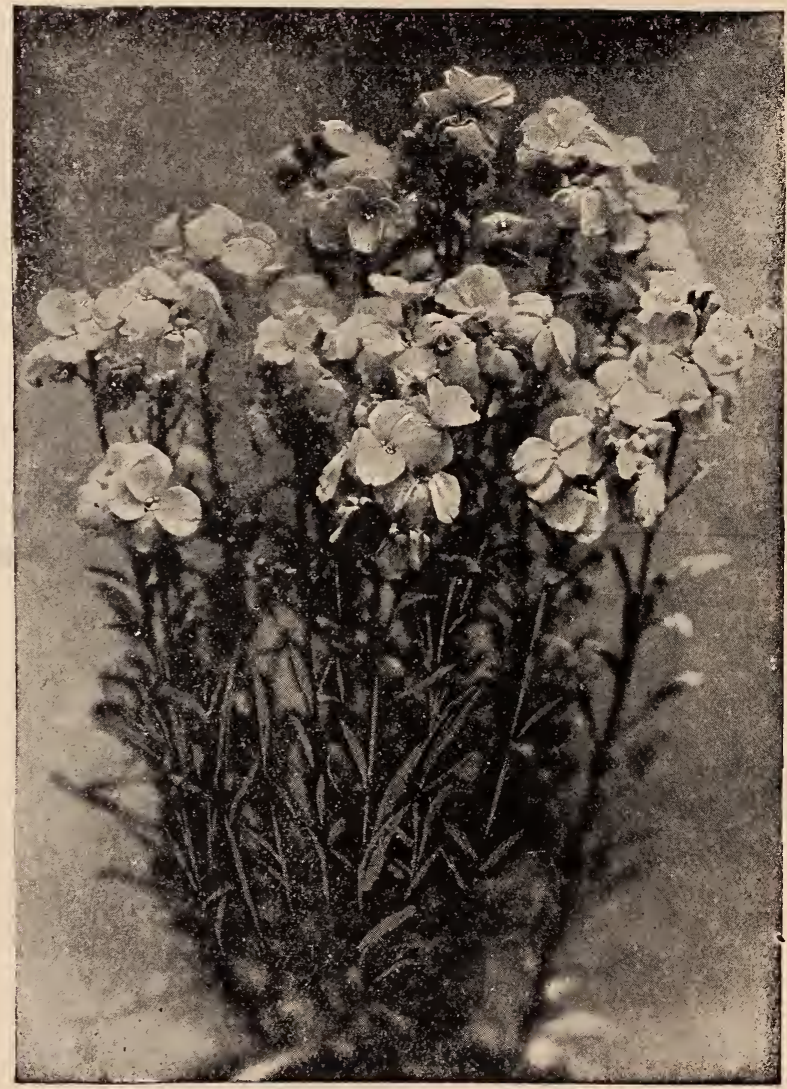




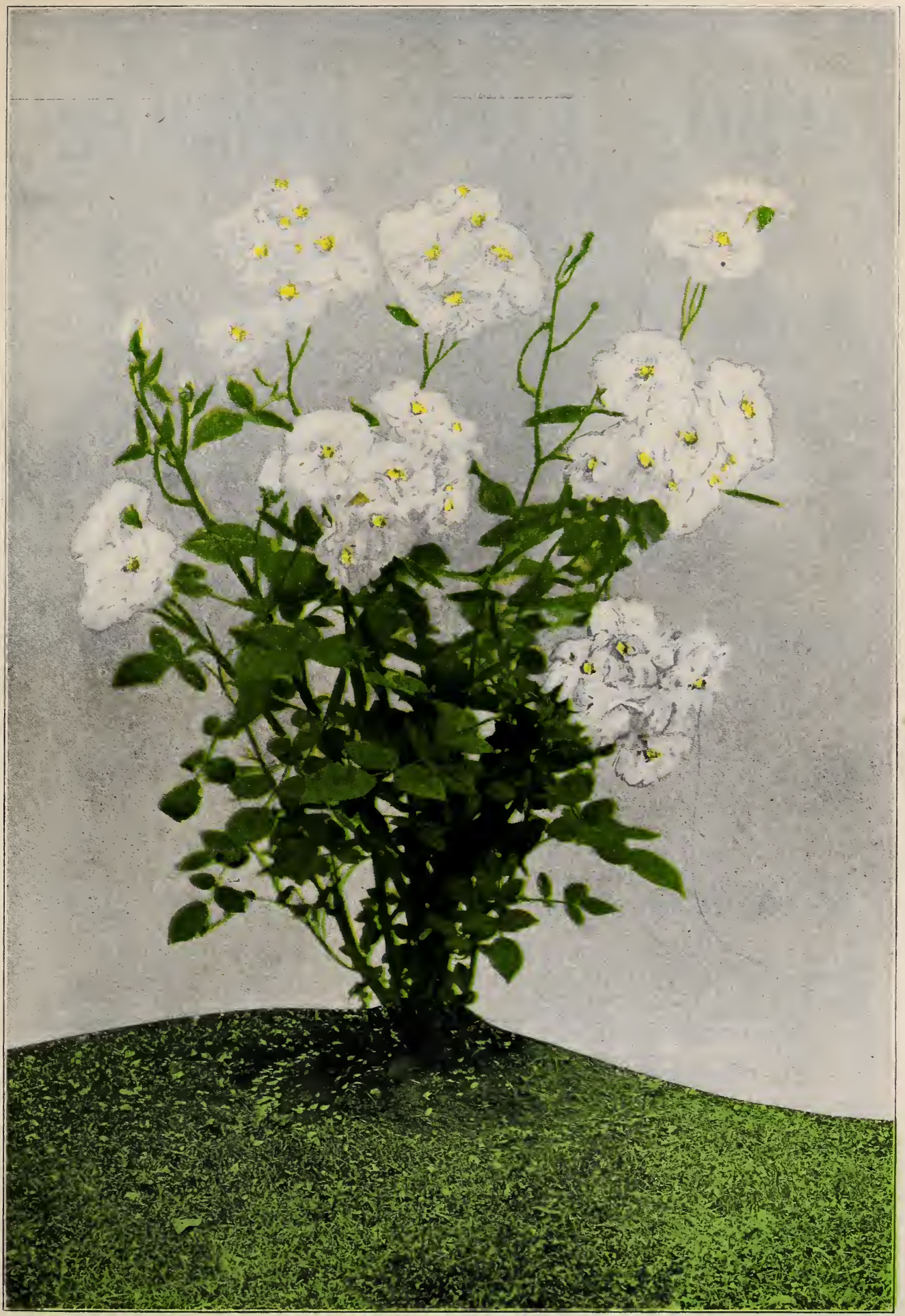

VREDENBURB \& CO INC ROCMESTER $N Y$ 


\section{WHITE

A charming companion to the well-known Crimson Baby Rambler. Of the same habit of growth; hardy; pure white, very double, and deliciously fragrant; makes a fine border or small hedge; blooms continuously. When planted in combination with Crimson Baby Rambler, the effect is very striking.

A Triplets Collection, consisting of

BABY RAMBLER (Crimson) WHITE BABY RAMBLER and BABY DOROTHY

(PINK-Same color as Dorothy Perkins).

We offer a fine block of strong, two-year-old field plants.

Price of strong, field-grown, 2-year-old plants, 25 cts. ea., $\$ 2.50$ per doz., $\$ 20$ per 100 ; plants from $2 \frac{1}{2} \cdot$ in. pots, 10 cts. each, 85 cts. per doz., $\$ 6.50$ per 100.

\section{THE \\ PALISADES \\ NURSERIES}

INCORPORATED

SPARKILL, N. Y. 


\section{PALISADES POPULAR PERENNIALS}

\section{OR OLD FASHIONED FLOWERS IN 100 VARIETIES}

Achillea (Milfoil)

Aconitum (Monkshood)

Aegopodium (Bishop's Weed)

Agrostemma (Rose Champion)

Alyssum (Mad Wort)

Anchusa (Sea Bugloss)

Anemone (Jap. Wind Flow er)

Anthemis (Chamomile)

Aquilegia (Columbine)

Arabis (Rock Cress)

Armeria (Sea Pink)

Artemisia (Southernwood or Old Man)

Asclepias (Butterfly Flower)

Asters (Michaelmas Daisy)

Aster (Alpine Daisy)

Baptisia (False Indigo)

Bocconia (Plume Poppy)

Boltonia (False Chamomile)

Callirrhoe (Poppy Mallow)

Campanula (Canterbury Bells)

Cantaurea (Hardy Corn Flower)

Chelone (Shell Flower)

Chrysanthemum (Giant Daisies)

Chrysanthemum Hardy Pompom

Cimicifuga (Snakeroot)

Coreopsis (Tick Seed)

Cosmary (Bible Leaf Plant)

Delphinium (Larkspur)

Dianthus (Hardy Carnation)

Digitalis (Fox Glove)

Eupatorium (Hardy Stevia)

Euphorbia (Flowering Spurge)

Funkia (Day-Lily)

Gaillardia (Aurora Flower)

Geranium (Hardy Geranium)

Geum (Red Buttercup)

Gypsophila (Baby's Breath)

Grasses (Ribbon Grass)

Helianthus (Hardy Sun Flowers)

Helenium (Sneezewort)

Heliopsis (Orange Sunflower)

Hemerocallis (Yellow Day-Lily)

Heuchera (Alum Root)

Hibiscus (Mallow)

Hollyhock, Double and Single

Iberis (Candytuft)

Iris (Fleur-de-lis)

Iris (Japanese)

Lathyrus (Everlasting Sweet Peas)

Liatris (Gay Feather)
Lilium (Hardy Lilies)

Linum (Blue Flax)

Lithrum (Loose Strip)

Lobelia (Cardinal Flower)

Lupinus (Lupins)

Lychnis (Ragged Robin)

Lychnis-Chalc. (Maltese Cross)

Lysimachia (Creeping Jenny)

Mertensia (Blue Bells)

Monarda (Horse Mint or Bee Balm)

Myosotis (Forget-Me-Not)

Nepeta (Variegated Ground Iry)

Oenothera (Evening Primrose)

Paeonies, Early Flowering

Papaver (Poppy, Oriental and Alpine)

Pardanthus (Blackberry Lily)

Pentstemon (Beard Tongue)

Physostegia (Dragon Head)

Physalis (Chinese Lantern Plant)

Phlox Decussata (Hardy Garden)

Phlox Subulata (Moss Pink)

Platycodon (Jap. Bell Flower)

Plumbago (Lead Wort)

Polomonium (Jacob's Ladder)

Polygonatum (Solomon's Seal)

Primula (English Primrose)

Primula (English Cowslip)

Pyrethrum (Persian Daisy)

Rudbeckia (Cone Flower)

Salvia Azurea (Rocky Mt. Sage)

Santolina (Lavender Cotton)

Scabiosa (Blue Bonnet)

Sedum (Stone Crop)

Sempervivium (House Leek)

Solidago (Goldenrod)

Spirea (Meadow Sweet)

Stokesia (Stokes Aster)

Sweet William (Dianthus)

Thalictrum (Meadow Rue)

Thymus (Creeping Thyme)

Tradescantia (Spider Wort)

Tricyrtis (Toad Lily)

Trillium (Wood Lily or Wake Robin)

Tritoma (Red Hot Poker)

Valeriana (Garden Heliotrope)

Veronica (Speedwell)

Vinca (Creeping Myrtle)

Viola Cornata (Johnny Jumpups)

Viola (Sweet Scented Violets)

Wallflower (English) 


\section{Some of the NOVELTIES and SPECIALTIES from our 1910 Catalogue}

SIBERIAN EDELWEISS. (Leontopodium Sibiricum.) The Edelweiss is well known to tourists who have travelled in Switzerland. This variety is distinguished by its simple culture and its very large white blossoms, which are twice the size of the Alpine variety. $25 \mathrm{cts}$. each, $\$ 2.50$ per doz.

HELIANTHI. (The wonderful new winter vegetable.) The greatest addition to the vegetable kingdom for many years. A complete substitution in taste for fresh asparagus. Yields half as much again as the potato.

Food Value-Dr. Koch, a well known food specialist, gives the following figures as units of food value: Helianthi 540.5, Green Peas 465.0, Turnips 133.0, Potatoes 126.8. This interesting comparison needs no comment. Price, strong plants, $15 \mathrm{cts}$. each, $\$ 1.50$ per doz.
Wonderberry, Sunberry or Garden Huckleberry. Much has been said for and against this plant.

Plants from 3 inch pots, that will bear the first year. $15 \mathrm{cts}$. each.

$\$ 1.00$ per dozen.

$\$ 7.50$ per 100 .

Seed, 10 cts. per packet.
ANCHUSA. Italica, Dropmore Variety. Sterling novelty. The splendid flowers are of the purest blue imaginable and produced on branched stems, growing about 4 feet high. Strong plants, 15 cts. each, $\$ 1.25$ per doz., $\$ 9.00$ per 100 .

ASTER (Michaelmas Daisy). Beauty of Colwall. The flowers are perfectly double, of a very pleasing shade of lavender; produced in great freedom on stout. erect stems, about 4 feet high. Awarded Certificate by the Royal Horticultural Society.

Strong plants 25 cts. each, $\$ 2.50$ per doz.r
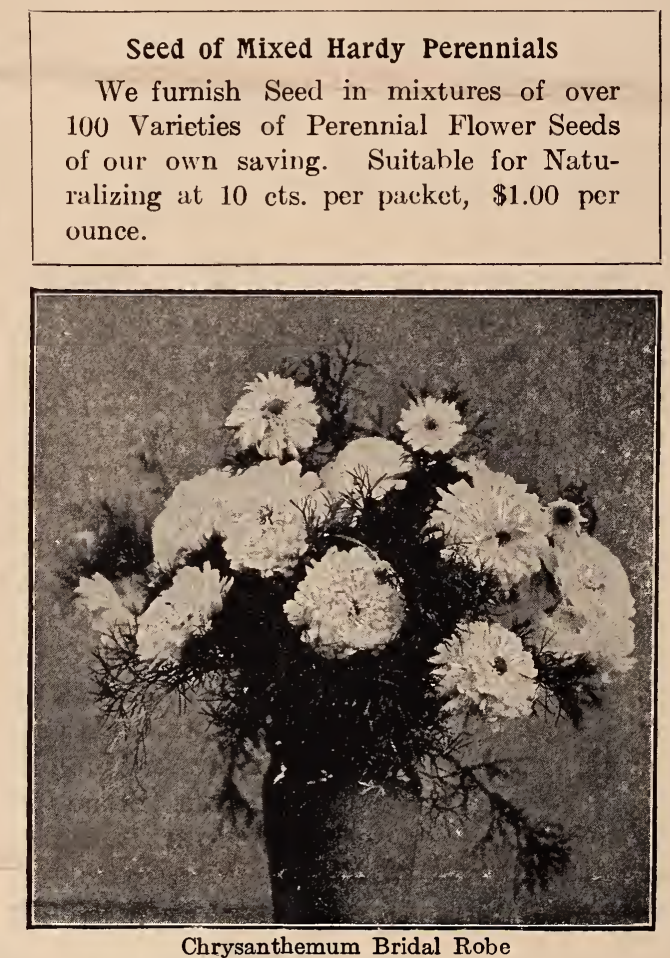

CHRYSANCHEMUM INODORUM (Bridal RObe)

Although this is said to be a Biennial, we find that for several years it comes up with us annually and withstands the most severe winters without injury. It is a magnificent border plant. Flowers continually the whole summer and fall, bearing large sprays of double white flowers in great profusion, very suitable for cutting, especially on account of its fern like foliage. See photo engraving. Strong plants 15 cents each, $\$ 1.50$ a dozen.

\section{CHRYSANTHEMUM}

Nipponicum. A hardy Japanese species. A variety worthy of special notice and not well known. Large Marguerite-like flowers, distinct, shrubby, with dark, spiny foliage; flowers during summer and autumn, but in milder climates during the whole year. $10 \mathrm{cts}$. each, $\$ 1.00$ per doz., $\$ 7.50$ per 100 .
DIANTHUS. COmtesse Knuth. New Hardy Yellow Carnation. Originated in Denmark and the introducers claim it to be perfectly hardy even in the most severe winters. The flowers are bright yellow, produced on stiff stems, 24 to 48 inches long. Plants from small pots, 50 cts. each.

PHLOX. Divaricata Laphami. (Perry's variety.) Most beautiful and distinct variety of the Divaricata or Canadensis class recently introduced. The flowers are much larger and brighter in color than those of Phlox divaricata. It is of a strong growing habit and flowers most abundantly from the middle of April till the end of July. Strong plants 15 cts. each, $\$ 1.50$ per doz., $\$ 10$ per 100 . 